\title{
Reading Galatians 6:16 in line with Paul's contrast between the new aeon in Christ and the old aeon before the Christ event
}

\author{
Du Toit, Philip la G \\ Stellenbosch University \\ plgdutoit@gmail.com
}

\begin{abstract}
This contribution argues for viewing 'the Israel of God' in Galatians 6:16 as pointing to God's people in the previous aeon before the Christ event. Prevalent interpretations of

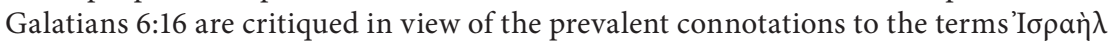

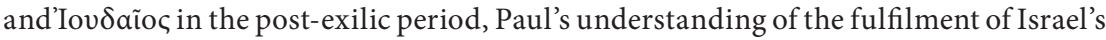
messianic hope, and the way in which Paul redefines identity in Christ and the Spirit. Galatians 6:16 is read with the third kai as a normal copulative (not epexegetically), constituting a contrast of the old aeon before or outside of Christ in the "flesh" under the law with the new aeon in Christ and the Spirit in Galatians and beyond.
\end{abstract}

Key words

The Israel of God; Israel's hope; Paul; Galatians; Identity; Messiah

\section{Introduction}

The aim of this article is to reconsider the prevalent interpretations of Paul's blessing on 'the Israel of God' in Galatians 6:16 and to interpret the referent of 'the Israel of God' in line with Paul's eschatology and his conception of salvation history. Since the referent of 'the Israel of God' involves identity, Paul's conception of identity with respect to his eschatology and his understanding of salvation history will be under discussion. In this discussion, an important question that will be considered is if Paul envisions Israel to continue after the Christ event in the letter to the Galatians.

Many contemporary approaches to identity in the New Testament utilise social-scientific categories as master categories to describe the totality of identity in the New Testament. Identity formation is normally seen as a 
process of negotiation between group norms and boundaries, which includes cultural phenomena such as ethnicity, honour and shame, patron and client relationship, and kinship language and relations (e.g., Buell 2005; Hodge 2007; Campbell 2008; Tucker 2010; 2011). In these approaches, Paul's "theologizing" is often included within or subordinated to social categories. An example is where Tucker (2011: 39) suggests that, rather than a prior theological reality displacing social categories, 'Paul's theologizing defines the Christ-movement in the context of social categories of identity, rather than to the exclusion of these'. Tucker is right that social identities are included within Paul's defining of identity, but by contrasting the defining of identity to a prior theological reality displacing social categories, he creates the impression that social categories are in fact higher in priority in defining identity than theological categories for Paul. This impression is heightened when Tucker (2011: 39) states that 'Paul's theologizing provides ideological justification for the formation of Christmovement social identity' (emphasis added), and that 'Paul's theologizing provides the social categories necessary for the formation of an 'in Christ' social identity' (emphasis added, ibid.: 41; cf. Campbell 2008: 161).

To work in the direction of subjecting Paul's 'theologizing' to socialscientific categories as ultimate, controlling categories for identity in Paul, could not only tend to be reductionist (Wright 2013: 28), but hold the danger of standing in too much tension with the theological core of Paul's gospel. In 1 Corinthians 1:22-24 (Collins 1999: 92; Ciampa \& Rosner 2010: 100) and 12:12-13 (Thiselton 2000: 795, 998), the spiritual identity in Christ is pictured in such a way that it transcends and relativizes social identities (cf. Wright 2013: 1443-1449). Similarly, in Galatians 3:28 social identities are portrayed as being included and made room for within an identity in Christ yet relativized (Dunn 1993: 207) to such an extent that they are not constitutive of the deeper controlling criterion of identity, which is Christ Himself. The fundamental social distinctions have been superseded by the new status of being in Christ, constituting the ruling criterion for being part of God's people (George 1994: 286-287; De Boer 2011: 243-244; cf. Hays 2000: 272-273; Schreiner 2010). ${ }^{1}$ Although incorporated within

1 Cf. also Col 3:9-17 (e.g., Moo 2008: 272-275) and Eph 2:8-22 (e.g., Perkins 2000: 400). This understanding of identity in Paul transcends an understanding where Paul merely 'accommodates' to social identities (contra Tucker 2011: 107). 
a redrawn identity in Christ, social categories that include ethnicity are not the ruling criteria of the new identity in Christ any longer (cf. Wright [2005] 2009: 113-119). In the light of the Scripture references mentioned above, the new identity in Christ can indeed be considered as a 'third entity' (Sanders [1983] 1989: 207; Wright 2013: 1443-1449; cf. Sechrest 2009: 15). Esler (2003: 144-145, 360) approaches identity in Paul with 'aid of' a social-scientific framework, and understands identity in Paul as a

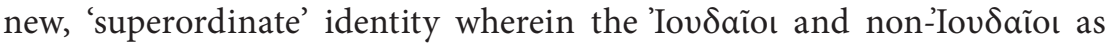
subgroups are incorporated yet enjoyed a 'relative status' (cf. Zoccali 2010: 176). Although the latter approach is a step back from viewing believers in Christ as a 'third entity', it already seems closer to Paul's theological thought than an approach where Paul's 'theologizing' is seen as being determined and controlled by a social category (e.g., Tucker 2011). ${ }^{2}$ The approach to identity in this article is to consider Paul's theological thought on identity as master category in approaching the question whether Paul envisioned Israel to continue in some way after the Christ event.

\section{Prevalent interpretations of Galatians 6:16}

In approximate order of popularity, the prevalent interpretations of Galatians 6:16 can be summarised within two main categories: (1) In the ecclesiological approach, 'the Israel of God' is understood as part of the church. Two main variants of this view can be identified: (a) Most interpret the 'the Israel of God' as 'those who will follow this rule' and thus as the community of all believers in Christ, including believers from the Gentiles

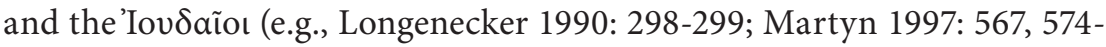
577; Hays 2000: 690; Cowan 2010: 78-85; Zoccali 2010: 78-83). (b) Others connect 'the Israel of God' to Christ-believers from the 'Iovdaĩo (i) who remain law-observant (De Boer 2011: 407-410) ${ }^{3}$ or (ii) who follow the rule of the new creation (e.g., Betz 1979: 323). (2) In the eschatological approach,

2 Cf. also Zoccali's (2013: 107) critique on Tucker (2010; 2011). Although Esler (2003: 4-5) resists the notion to speak of Paul as 'theologian' (in terms of a systematic enterprise), he does leave room for 'theology' in Paul in terms of the sum of the beliefs held by an individual or group regarding their faith.

3 De Boer (2011:408) incorporates an anticipatory element (not necessarily eschatological) wherein mercy upon law-observant, Christ-believing 'Iov反aĩo ('the Israel of God'), 'looks to their eventual conversion to Paul's understanding of the gospel and indicates that the anathema of 1:6-9 is not eternal'. 
'Israel' is seen as a distinct entity from the church that continues existence after the Christ event. 'The Israel of God' is understood as those in continuity with historical Israel who will believe in Christ in the future (e.g., Burton 1920: 357; Richardson 1969: 81-84). On the basis of their interpretation of Romans 11:26, some connect 'the Israel of God' specifically to an anticipated eschatological miracle of current Jews who will be saved (e.g., George 1994: 473-474; Johnson 2009: 53-54; Schreiner 2010: 381-383, 386).

\section{Critiquing prevalent interpretations of Galatians 6:16}

As proposed earlier, the main question regarding both of the above approaches is whether Paul in Galatians envisioned Israel to continue in some way after the Christ event. This question especially applies to the eschatological approaches (2 above) for it envisions Israel to exist as a distinct entity over and above the Christ-believers. Within the ecclesiological approaches ( 1 above), those that see 'the Israel of God' as a sub-group of 'Iov反aĩo among the Christ-believing community (1b above) presupposes that 'the Israel of God' is a distinct sub-group among Christbelievers. Even the interpretation that 'the Israel of God' is all the Christbelievers irrespective of ethnic heritage (1a above), presupposes an 'Israel' after the Christ-event, even though such an 'Israel' is redefined. There are however several hermeneutical difficulties surrounding these prevalent interpretations of Galatians 6:16 that will be addressed below.

\subsection{The hermeneutic differences between the designations'I $\sigma \rho a \grave{\lambda} \lambda$ and'Iov反aĩos}

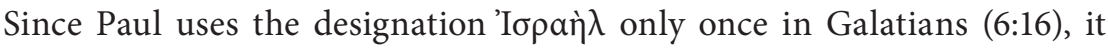
has to be asked what the relationship is between the designations' $I \sigma \rho a \eta े \lambda$ and 'Iov反aĩos. Are they exact synonyms or do they carry different connotations, and if so, what is the measure of overlap in the way Paul applies these designations? It is significant that the use of the designations

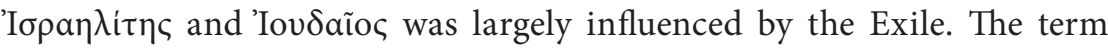

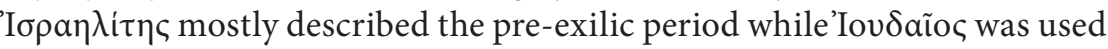
for the people of the second temple (Kuhli 1991b: 205). This tendency is especially recognisable with Josephus (Tomson 1986: 123-124, 137-139;

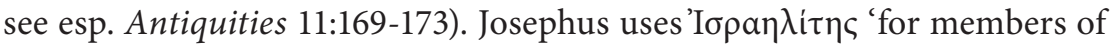
the people of God in past days. He does not use it for present members' 


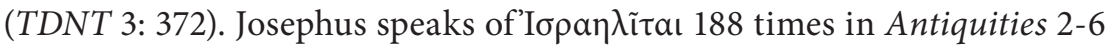

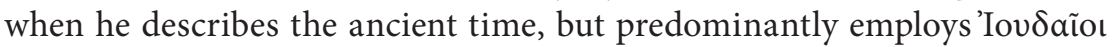
from Antiquities 6.6 onward and exclusively from 6.317 right up to the end (Kuhli 1991b: 205). Kuhli (1991b: 205) writes (cf. Jewett 2007: 561-562):

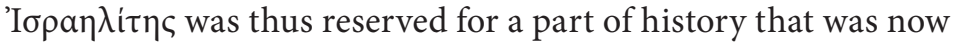
closed. Its use by a contemporary Jew must, therefore, have been an archaism limited to specific occasions and rhetorical formulas of address (cf. 4 Macc 18:1). ${ }^{4}$

Further, in the time of the second temple, the term 'Iovdaĩos was more

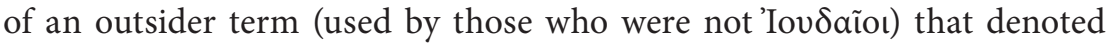
contemporary ethnic people without necessarily carrying strong

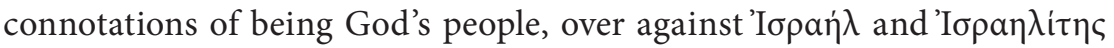
as mostly insider terms that denoted God's people (TDNT 3: 360; Tomson 1986: 20; Khuli 1991a: 204; 1991b: 205; Campbell 1993: 441; Elliott 2007:

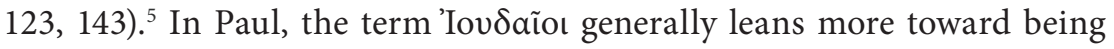
an ethnic designation ${ }^{6}$ in his present, and apart from most prevalent interpretations of Romans 11:26 and Galatians 6:16, the designation

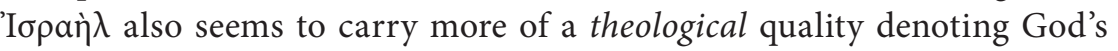
elect people (TDNT 3: 357; Kuhli 1991a: 204) in Paul's past (Campbell 1993:

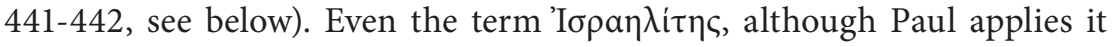
twice as a self-designation (2 Cor 11:22; Rom 11:1) seems to lean more toward the historical side in the sense that it denotes Paul's historical line of descent. The question is, did Paul's use of I $\sigma \rho a \grave{\lambda} \lambda$ transcend the prevalent limits of Judean ${ }^{7}$ speech as Tomson (1986: 287-288) suggests, which would

44 Macc 18:1 reads: 'O Israelite children, offspring of the seed of Abraham' (NRSV).

5 Even Miller (2010: 109) seems to admit to the tendency to view the term 'Israel' as a term that predominantly denoted God's people of ancient, Old Testament times when he ascribes the predominance of the term 'Israel' in Jubilees 'to the fact that the storyline in these two books retells ancient Israelite history'. Yet Miller points out that

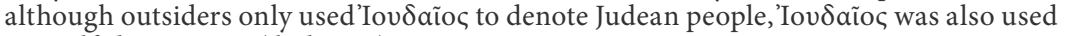
as a self-designation (ibid.: 100).

6 The most notable exception is probably Rom 2:29 where Paul rhetorically alludes to the inherent meaning of'Iov反aĩoc (Du Toit 2013: 82-89).

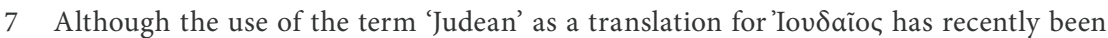
disputed (e.g., Miller 2014: 255-259) in terms of possible anti-Semitic notions, I still view the translation 'Judean' as more appropriate to account for the hermeneutic distance between the 'Iov反aĩo in the time of the second temple and today's 'Jews'. Although there would be an extent of overlap between what ancient people considered as distinct 


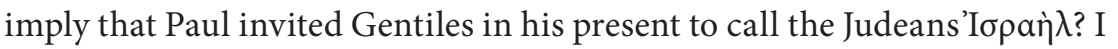
would propose a negative answer to this question in viewing the prevalent use of these terms in the time of the second temple as a priori constraints in interpreting Paul.

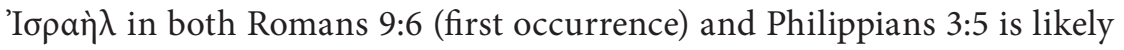
to point to the patriarch 'Israel', denoting Paul's line of descent from

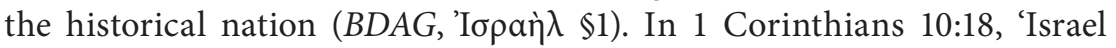
according to the flesh' is probably best seen as historical Israel in view of the historical example that alludes to Leviticus 7:6, 15 and Deuteronomy 18:1-4 (Collins 1999: 380; Fitzmyer 2008: 329). In 2 Corinthians 3:7, 13 the expression 'sons of Israel' is set in a historical setting of the glory of Moses' face and the veil over his face. Notwithstanding the disputed status of Ephesians, chapter 2:12 points to the historical situation where those without Christ were alienated from the commonwealth/citizenship of Israel. Although one could point to Romans 9-11 in identifying an example

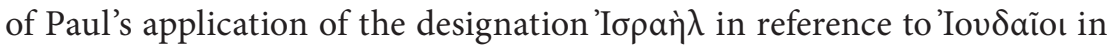
his present, it is methodologically more rigorous to interpret Galatians 6:16 without evoking Romans 9-11, especially since the context of Romans 9-11 is very different from Galatians (Campbell 1993: 442). Yet, even in Romans 9-11 it is not that obvious that the term'Iopàे $\lambda$ in itself should necessarily

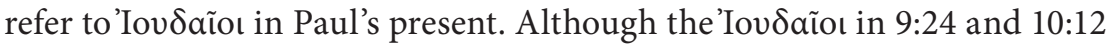
certainly point to the 'Iov $\delta$ aio his present and stand in continuity with

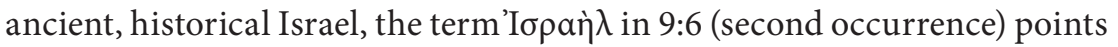
to historical Israel as an 'inner Israel' or 'true Israel' within the whole historical nation. The reason being that Paul connects them to the promise given to Abraham in history (vv. 8-9) and to Isaac, the promised child (v. 10). He then points to Jacob and Esau as representative of two nations in the history of salvation, representing 'true Israel' (v. 13, Cranfield 1979: 479, see Gen 25:23). In 9:27'Iopà̀ $\lambda$ is used in the context of historical Israel, quoting Isaiah 10:22-23. In 9:31, Israel is mentioned in connection with their historical striving for righteousness based on the law in which they did not succeed. In terms of the course of salvation history, they stumbled over the stumbling stone that is Christ (v. 32, Moo 1996: 628-630; Wright 2002: 643,

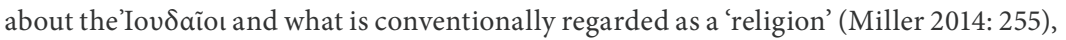
it would still be more appropriate to consider the'Iov $\delta$ aĩo of the second temple as more of an ethnos than a 'religion' in the strict sense (Mason 2007). 
650). In 10:19, 'Israel' is used in context of Deuteronomy 32:21 that denotes historical Israel. Their hardening and even their provocation to jealousy via other nations can be identified historically (cf. Cranfield 1979: 539). In 10:21 the term 'Israel' is applied in context of Isaiah 65:2 that once again points to Israel's historical hardening. Seifrid (2004: 144) notes that historical Israel's recalcitrance and rebellion is a condition that extended into the present for Paul. In 11:2-3, 'Israel' is mentioned in connection with their killing of the prophets and their demolition of the Lord's altars (1 Kings $19: 10,14)$. According to 11:7, Israel did not obtain what it was seeking. This repeats the same notion as in 9:31-33, which points to Israel's failure during the course of salvation history that culminated in their stumbling against the stumbling stone (Du Toit 2013: 293-294). Although 11:11-24 does not mention Israel by name, it denotes Israel's rejection and fall in terms of the history of salvation that brought the riches to the world in Christ. In respect of salvation history, they were 'cut off' as branches from the 'root', representing God's people of the old aeon before Christ (Du Toit 2013: 300 301; cf. Fitzmyer 1993: 614). Paul acknowledges the possibility of the broken branches to be grafted into the tree again if 'they' do not stay in unbelief,

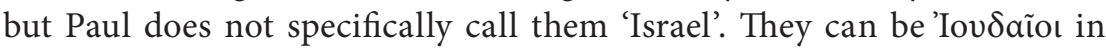
his present who stand in continuity with historical Israel (Du Toit 2013: 335-336). Although most interpreters read 'Israel' in 11:25-26 futuristically, I have argued in some length elsewhere ( $\mathrm{Du}$ Toit 2013: 310-345; 2015) that even there 'Israel' can be understood as denoting the salvation of historical Israel as a result of the 'coming in' of the Gentiles in salvation history (v. 25), where the latter could point to their generic inclusion in God's salvific economy through Christ's death and resurrection, and not to their individual salvation as such in Paul's future. ${ }^{8}$ In this reading, 'Israel' that 'will be saved' is understood as a logical future that is future from the prophecy in verses 26-27 (futurum propheticum, Fitzmyer 1993: 625) but could have been realised within the first Christ advent. ${ }^{9}$ Apart from

8 This understanding would echo the same notion as 9:24-26, 30 and 11:11 where the Gentiles have generically been included in God's salvific economy in Christ. The

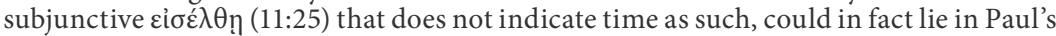
past (cf. a similar use of the subjunctive $\varepsilon \hat{\varepsilon} \lambda \theta \eta$ in Gal 3:19, denoting the seed [Christ] that came).

9 Some of the other arguments that I advance in support of this position that cannot be repeated in length here (Du Toit 2013; 2015) are the following: (1) Paul never 
Romans 11:26 then (of which a futuristic interpretation can be disputed), the term 'Israel' in Paul thus seems to lean toward the salvation-historical side before the Christ event.

\subsection{Messiahship and the fulfilment of Israel's hope in Paul}

Paul's conception of messiahship, which involved his understanding of the fulfilment of Israel's hope, directly influenced the way he perceived identity, which in turn pertains to the question whether Paul would envision Israel to continue as a distinct entity after the Christ event. Even though one cannot determine its extent with certainty, there was a reasonably widespread hope in the time of the second temple that there would come a king through whom Israel's God would liberate His people (Wright 1992: 308; Fitzmyer 2007). ${ }^{10}$ This hope, which has taken on an explicitly Davidic form in at least one case in the form of Simon bar Giora in 66-70 CE (Horsley \& Hanson 1985: 120-122), was certainly current at the turn of the common era (Neufeld 1997: 120-121; cf. Horsley 2001: 244). Much of this expectation would have been based on the Scriptural promise that David's kingdom would be established eternally (Wright 1992: 310; Hays

pertinently answered the underlying question in the build-up of Romans whether historical Israel that lived before the Christ event is saved. (2) The 'mystery' (Rom 11:25) elsewhere in Paul mostly relates to the gospel in Christ (Rom 16:25; 1 Cor 2:1,7; 4:1; cf. Eph 1:9; 3:3,4,9; 6:19; Col 1:26,27; 2:2; 4:3), making it likely that the 'mystery' in 11:25 also relates to the first Christ advent. (3) The 'hardening' (v. 25) is rooted historically (Rom 10:19-21; 11:1-10; 2 Cor 3:14) and thus pertain to historical Israel, although continuing into Paul's present. (4) The prophetic language around the Deliverer (Rom 11:26-27) could pertain to Christ's first advent (involving the taking away of sins and a [new] covenant/testament, referring back to 9:33 where Zion is the place of Jesus' crucifixion). (5) The Deliverer is the subject of the actions in the prophetic citation (11:26-27) which strictly excludes repentance or conversion by the subjects as such (cf. Isa 27:6-13). (6) The 'hardened' (Rom 11:25) and the term 'I $\alpha \kappa \omega \beta$ (Rom 11:26) seem to paradoxically correspond to inner-elect Israel (in contrast to national Israel, Rom 9:6), and would echo similar paradoxical notions to those in Isa 27:6-13 (see esp. 'those being exterminated' [האבדים in v. 13] who paradoxically worship the Lord on the holy mountain at Jerusalem), which in turn would relate to the mystery of Rom 11:25. (7) This interpretation would fit the larger salvation-historical context in Romans and

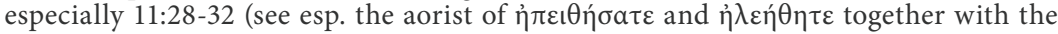
adverb v $v$ in Rom 11:30 that seem to point to the realised significance of the Christ event, and the second $v \tilde{v} v$ in Rom 11:31 [ $\mathrm{N} \mathrm{D}^{*}{ }^{* c} 1506$ pc bo fay ${ }^{\mathrm{ms}}$ ], which in turn could suggest that Israel already received mercy for their historical hardening).

10 Novenson (2009: 364-365) indicates that this is one of the things that messiah language could signify in what he calls 'Roman-era Judaism'. The Roman authors of the time would also have known the idea of a prophesied universal rule by a Judean king. 
2006: 60; Fitzmyer 2007: 7, 33-55; see 2 Sam 7:4-29; Ps 89:3-4; 132:11-12; cf. 4QFlor 1:10-13).

Although messianic expectation in the time of the second temple was not uniform (being both royal and priestly), ${ }^{11}$ it is probably safe to say that the fundamental hope was for liberation from oppression, for the restoration of the Land, and for the proper rebuilding of the Temple. These beliefs were grounded on the one hand in believing that Israel's one God was the king of the world, and on the other hand, facing the fact of Israel's present desolation. A central way of expressing this hope was the division of time into two eras: the present age (הזה עולם) and the age to come (עולם הבּא). The present age was the time of Israel's misery, and in the age to come Israel would be restored (Wright 1992: 299; 2003: 557; cf. Weinfeld 1997: 218-219). ${ }^{12}$

Paul saw Christ as the Messiah from the historical nation of Israel (Rom 1:3-4, Moo 1996: 46; Wright 2002: 415-416; Rom 9:5, Wright 1992: 307320; 2002: 629; Moo 1996: 565). For Paul, Jesus' Davidic messiahship is confirmed by the title: 'root of Jesse' (Rom 15:12, Moo 1996: 880; Wright 2002: 748; cf. Dunn 1988: 850), which Novenson (2009: 369) considers 'fullfledged messianic exegesis [of Isaiah 11:10] on the part of Paul' (cf. Hengel 1983: 69). In Wright's (1992: 406-407; 2002: 691; 2003: 726; 2013: 1061-1078) understanding of Paul, the exile has been undone in the Christ event, God's people's sins are forgiven and the covenant has been renewed in Christ and the Spirit. Israel's God had poured out His Spirit on all flesh and His Word was going out to the nations, calling into being a new unified people in Christ, including all nations. In this sense, the end had come and Israel's eschatological hope has been fulfilled, although redrawn and renewed.

When Paul discusses the promises to Abraham (Gal 3; Rom 4), it is noteworthy that Paul neither mentions anything of the inheritance of land that was part of the promise to Abraham and formed part of Israel's expectation (e.g., Gen 12:7; 13:15-17; Isa 57:13; 60:21), nor of Israel's national reign over the nations (e.g., Isa 11:10-14; 42:1,6; 49:6; 54:3; Jer 4:2; 23:5) through a worldwide earthly dominion of the Messiah (e.g., Ps 72:8-11; Isa

11 This is especially evident from the Dead Sea Scrolls (Knibb 2010: 420-421).

12 The hope for Israel's restoration via a divine kingdom (e.g., Ps 68:8-9,16-18; Hab 3:3; cf. Dan 7:13-14; Ps Sol 17:21-32) can be traced back to God's dealings with Israel as a king (Deut 33:2,5; Ex 15:18; Num 23:21-22; 24:7-8; Weinfeld 1997: 218-219). 
9:7; Jer 23:5). Rather, believers now inherit the whole cosmos (Rom 4:13), which points to all of humanity (BDAG, кó $\mu$ o $\$ 6 \mathrm{a})$ which is Abraham’s seed (Wright 2002: 496), or points to the restoration of the whole created order that transcends a territorial understanding of the promise of the land to Israel (cf. Dunn 1988: 213). The Messiah's reign is now of a different kind (Wright 2013: 911, 1065): He reigns over the dead and the living (Rom 14:9; cf. 15:12). ${ }^{13}$ The promises to Abraham in terms of the one new family of Judean and Greek believers in Christ (Wright 2002: 535; 1 Cor 12:1213; Gal 3:28) is therefore fulfilled in a way different from prevalent Judean messianic expectations in terms of (1) Abraham's seed, (2) the land and (3) the reign of God through His people. The transformation of Israel's messianic expectation is directly related to Jesus' bodily resurrection and transformation, which in turn vindicated His messiahship and transformed messianic belief (Wright 2003: 562-563, 726-728).

The fundamental difference between Paul's eschatology and prevalent expectations in the time of the second temple (see above) is that Paul understands messiahship as fulfilling Israel's hope in a different way than expected: God's rule and kingdom is not a kind of rule that involves political territory or a physical temple. Rather, God's rule is a cosmic rule (Rom 14:9; 15:12; Php 2:9-11) wherein God's people enjoy heavenly citizenship (Php 3:20) and cosmic inheritance (cf. Rom 4:13). God's people are the new temple (1 Cor 3:16-17; 6:19; 2 Cor 6:16; cf. Eph 2:21) and the Messiah's body in this world (Rom 12:5; 1 Cor 12:27; cf. Eph 4:12; cf. Wright 2013: 10731074).

\subsection{Christ and the Spirit as realised eschatological events that redefine identity}

In conjunction with Paul's view of the kingdom as something that is of a different kind, his understanding of the Christ event and the Spirit is central to his conception of Israel, salvation history and eschatology. For Paul, both the indwelling Spirit and Christ's resurrection can be understood as first fruit (å $\pi \alpha \propto \chi \dot{\eta}$, Rom 8:23; 1 Cor 15:20, 23) of the general bodily

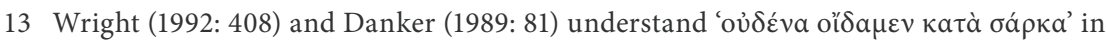
2 Cor 5:16 such as that the Corinthians do not know Jesus as a national Messiah any longer. 


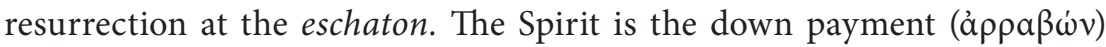
to believers that they will be clothed with a heavenly body and eternally dwell with God (2 Cor 5:4-8). Christ's resurrection is therefore an innately eschatological event, 'in fact, the key inaugurating event of eschatology. His resurrection is not an isolated event in the past but, in having occurred in the past, belongs to the future consummation and from that future has entered history' (Gaffin 1998: 575).

That Paul's gospel is profoundly eschatological, is confirmed by many Pauline scholars of which two of the most prominent are arguably Beker (1982) and De Boer (2002; 2011). In Beker's (1982: 40) understanding of Paul, the powers of the new age are already at work, of which the church is a sign. He states (Beker 1982: 75):

The eclipse of the imminent cosmic expectation of the kingdom of God coincides here with a view that considers the Christ-event essentially as the centre and fulfilment of all of God's promises. And so the eschatological consummation becomes an extrapolation from the central event of Christ.

Beker $(1982: 76,88)$ locates the centre of Paul's thought in his christologically determined future apocalyptic. For De Boer (2002: 22-24; 2011: 393), the essential characteristic of Paul's 'apocalyptic eschatology' is the dualism of two world ages: it is only through the disclosure of the coming age that the present age can be perceived as 'this (evil) age' (Gal 1:4). It entails God's own eschatological, sovereign action of putting an end to this world-age and by replacing it with the new-world age (cf. Martyn 1997; 2000).

The distinction between the two ages, before and after the Christ event, can especially be derived from Paul's dichotomy between $\sigma \alpha \dot{\alpha} \xi \xi$ and $\pi v \varepsilon \tilde{v} \mu \alpha$ in their extended application. Although $\sigma \alpha \dot{\alpha} \xi$ and $\pi v \varepsilon \tilde{v} \mu \alpha$ and their cognates

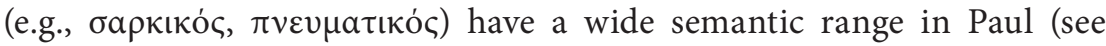
esp. Bruce [1985] 2000:48-59), the deepest, most extended meaning of the contrast they represent is arguably best expressed in passages such as Romans 7:5-6; 8:4, 5, 8-9 and Galatians 5:16-17, 25. In these passages $\sigma \dot{\alpha} \rho \xi$ and $\pi v \varepsilon \tilde{u} \mu \alpha$ bear a distinct eschatological meaning within the framework of salvation history which can be summarised as follows:

- $\sum \dot{\alpha} \rho \xi$ in its extended application constitutes an aeon and way of existence in Adam prior to or outside of Christ, which is defined by 
and under the control of the Mosaic Law, $\sin ^{14}$ and death (cf. Moo 1996: 49-50). $\sum \dot{\alpha} \rho \xi$ thus stands for a mode of identity marked off by external, observable, human markers of identity.

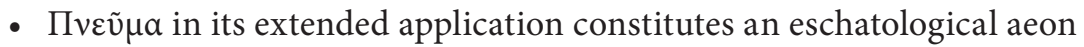
and way of existence in Christ and the Spirit, which is defined by and under the control of the indwelling Spirit, which is a consequence of the new creation (having both corporate and individual significance). $\Pi v \varepsilon \tilde{u} \mu \alpha$ thus stands for a mode of identity marked off by the internal work of the Spirit, which constitutes adoption as God's children (cf. Barclay [1988] 1991: 212-215; Fee 1994: 469-470, 553, 816-822; 1996: 88; Moo 1996: 49-50; Jewett 2007: 436-437, 486; Hansen 2009: 221).

The Christ event can therefore be understood as inaugurating the new aeon and new way of existence in the Spirit which completes and supersedes the previous aeon. In the new aeon in Christ, identity is no longer defined or partly defined by external identity markers such as the law (including circumcision) which can be described as being in the realm of 'flesh'. In the new aeon inaugurated by Christ, God's indwelling Spirit that bears witness with the human spirit constitutes being God's people (Rom 8:16; Du Toit 2013: 277-279). The eschatological significance of the indwelling Spirit can thus be described as the deepest theological identity-constraint against viewing Israel as continuing as God's people in some way after the Christ event.

\section{Reading Galatians 6:16 in the light of contrasting aeons}

In light of all the above, the notion that Paul would have envisioned 'Israel' as a distinct entity after the Christ event, whether they would be a subgroup within the Christ-believing community or distinct from them, is not that evident. Any 'Israel' apart from the ecclesia would be an 'Israel according to the flesh' (1 Cor 10:18), which goes against the grain of the deeper criteria for identity in respect of being God's people, especially if God's people have been redefined in terms of the eschatological Spirit/spirit over against flesh (Rom 8:1-16). Any existence in the flesh (Rom 7:14-25) as a way of existence

14 Although Paul often uses $\sigma \alpha \dot{\rho} \rho \xi$ in relation to sin (e.g. Rom 7:14; 8:3; Gal 5:19) it not so much as if $\sigma \dot{\alpha} \rho \xi$ equals inherent sinfulness in human beings ('sinful nature'), but rather that $\sigma \alpha \dot{\alpha} \rho \xi$ denotes a way of existence under the reign of sin (e.g., Fee 1994: 430 on Gal $5: 16,19)$. 
(of being God's people) before or outside of Christ ${ }^{15}$ has been cut off (Rom 8:9; cf. 9:32-33; 11:7, 12, 17-24) and have died in Christ (2 Cor 5:15-16; cf. Gal 2:20; see Du Toit 2013: 152-160, 181, 205-211, 289-303).

In Paul's letter to the Galatians, he portrays the Christ event as the climax of salvation history where righteousness through faith and the Spirit is inaugurated (2:16; 3:2-3, 8-9, 13-14, cf. Wright [1991] 1993: 157-174). Faith and the Spirit is opposed to the 'works of the law' $(2: 16 ; 3: 2,5,10)$ and the 'curse of the law' (3:13). Christ is the seed of Abraham that should 'come' $(3: 16,19)$. The promise is given to believers on the basis of the Christ event $(3: 22)$. Faith is thus portrayed as something that 'came' $(3: 23,25)$. The aeon of faith and the aeon 'under die law' (3:23) are thus contrasted as two distinct salvation-historical aeons and ways of existence on either side of the Christ event (Fung 1988: 167-170; Fee 1994: 385; Martyn 1997: 323; De Boer 2011: 239; cf. Betz 1979: 175-176; Lategan 1986: 71; Schreiner 2010; Moo 2013: 22, 240-244). According to chapter 4, Christ is pictured as being born 'under the law' at the 'fullness of time' that those 'under the law' might be redeemed and obtain adoption unto childhood (litt. 'sonship') by the Spirit who works in the hearts of people (vv. 4-5). The coming of Christ thus constitutes a new way of existence and mode of identity. The allegorical image of the free and slave woman (4:21-5:1) can be understood as the contrast of the Old and New Covenants (e.g., Fee 1994: 413, 416; George 1994: 339), implying two exclusive ways of existence (Meyer 2009: 129, 136-137)..$^{16}$ The Jerusalem above, representing the eschatological people of God in the new aeon in Christ is contrasted to the present Jerusalem of the old age, the age of slavery (4:25-26). This latter contrast ends up being the key opposition in Galatians 4 (De Boer 2011: 301). Yet the two exclusive, 'eschatological' ways of existence is also evident in Galatians 5:16-25, where the contrast between 'S/spirit' and 'flesh' is ultimately absolute,

15 In this interpretation, Rom 7:14-25 is taken as pointing to someone before or outside Christ (e.g., Fee 1994: 511-515; Moo 1996: 447-449; Wright 2002: 551-553; Jewett 2007: 462-473; Kruse 2012: 298, 305-311).

16 Although some understand the contrast in Gal 4:22-5:1 as one covenant in terms of two different understandings (e.g., Dunn 1993: 249; Hays 2000: 302), this line of argumentation becomes strenuous in context of the birth of the two sons of Abraham (vv. 23, 29) who each represent one of two actual covenants (v. 24), and thus has salvation historical significance (Longenecker 1990: 213; cf. Bruce 1982: 217). Cf. how 'Abraham' (Rom 4; Rom 9:7; Rom 11:1; 2 Cor 11:22 and Gal 3) and 'Isaac' (Rom 9:7, 10) feature elsewhere in the context of the Old Covenant (Du Toit 2013). 
representing two exclusive eschatological aeons and ways of existence: the one before or outside of Christ and the other one in Christ wherein the eschatological Spirit has already come. Such a view seems certain from the context where life 'in the flesh' is described in terms of a former way of life (vv. 19-21a) whose eschatological end is that they will 'not inherit the kingdom of God', and from verse 24 that pictures the life of the believer such as having 'crucified the flesh with its passions and desires'. Christ and the Spirit thus mark the turning of the ages, and therefore, 'life in keeping with the flesh' and 'life by the Spirit' are mutually incompatible options (Fee 1994: 431, 438; cf. De Boer 2011: 354).

In Galatians 6, by the image of sowing and reaping (vv. 7-8), Paul takes his readers back from a narrower horizon of specific exhortations in verses 1-6 to the broader view of the S/spirit-flesh dichotomy of 5:13-26 (Fung 1988: 294). In the harvest metaphor, Paul thus reunites the antinomic motifs that were dominant in the entire argument: life in the eschatological Spirit against life in the flesh. Paul's reference to sowing 'unto his own flesh' thus involves 'sowing unto' their former unregenerate identity of the old aeon (cf. Bruce 1982: 265; Lategan 1986: 113; Fee 1994: 466-467). The end result of an identity defined by 'flesh' is corruption ( $\varphi \theta 0 \rho \dot{a}$, v. 8). Conversely, to 'sow in the S/spirit' (v. 8) is another way of pressing the imperatives as implied by 5:16-26: to 'walk' by the Spirit, being 'led' by the Spirit and 'bearing the fruit' of the Spirit (Fee 1994: 465). In reference to 'eternal life' (v. 8), there is an unmistakable eschatological orientation attached to the exhortation contained within the harvest metaphor (Fee 1994: 465; cf. Lategan 1986: 113; Hays 2000: 337). 'Eternal life' is the end result of this new way of existence in the Spirit.

The cross (vv. 12,14) is set over against flesh (vv. 12, 13), law (v. 13) and circumcision (vv. 12, 13, 15). The cross stands against an identity that was defined around the law, especially in terms of the antinomy constituted by being circumcised or not (cf. Martyn 1997: 560). When Paul writes that 'the world has been crucified to me, and I to the world' (v. 14) the cross does not only signify Paul's 'crucifixion' to his former life as a Pharisee (Fung 1988: 307), but it signifies a 'watershed event for the whole cosmos, affecting everything after it' (Martyn 1997: 564; cf. George 1994: 470). For Paul, the cross denotes the transplantation from 'one sphere of existence to the other' (Fung 1988: 307; cf. Bruce 1982: 273; Betz 1979: 320). The underlying 
notion is that the cross stands 'for the Christ-event as a whole' in that it 'marks the end of the old world and ushers in the new' (Fung 1988: 307; cf. Hays 2000: 344). As Lategan (1986: 115) describes it, 'the cross is for Paul the central symbol to which the truth of the gospel is attached and wherein the transition of the way of existence of the world to the way of existence of the faith is expressed' (translated). The implications for the understanding of identity (v. 14) can hardly be better described than by Hays (2000: 344):

[Paul's] previous identity has disappeared altogether, and his new identity is given him only through his participation in Christ, who animates the life he now lives (Gal 2:19-20). That is why he can also say that the flesh has been crucified for those who belong to Christ. They participate, not just symbolically but actually, in his death; therefore, they have entered the new eschatological world where his life empowers the community to 'walk in newness of life' and consider themselves 'dead to sin and alive to God' (Rom 6:4, 11 NRSV).

In Galatians 6:16, following Paul's ongoing juxtaposition of the Old and New aeons and ways of existence up to this point in the letter, those following 'this rule' (the new creation) could thus naturally point to those in the new, eschatological aeon, while 'the Israel of God' could naturally point to historical Israel that lived before the Christ event. Up to this point, Paul has pictured the new aeon and the new covenant in sharp discontinuity with the former age. The only continuity that God's people now have with the old aeon is punctilio, by faith in the Seed of Abraham, which is Christ. Paul therefore might have left the impression that the new aeon in Christ has completely nullified the former aeon wherein Israel lived (cf. Martyn 1997: 350). In contrast to the first half of verse 16, one could therefore expect a last minute measure of balance that pertains to the old aeon in the

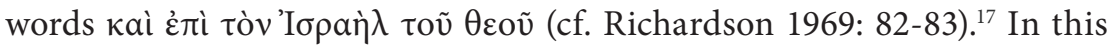
understanding, Paul blessing would thus span all God's people over two salvation-historical aeons.

17 Although Richardson (1969: 82-83) understands 'the Israel of God' eschatologically, he has a similar idea when he writes that 'from the way Paul has argued previously in the letter, one might infer that he was condemning everything about Israel. To forestall this inference he includes this prayer to God for mercy to be shown to Israel.' 
Other considerations that supports this interpretation are the following: (1) The third kai in this verse probably functions as a normal copulative, representing a contrast between those walking by 'this rule' and 'the Israel of God' (e.g., Dunn 1993: 344-345; De Boer 2011: 406). (2) The notion that

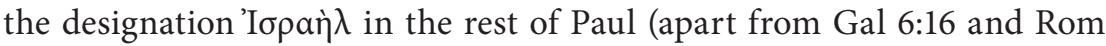
$11: 26)$ carries any eschatological or ecclesiological connotation is absent. (3) The idea to refer to believers in Christ as 'Israel' is absent in the early church until 160 CE where Justin in his Dialogue with Trypho (11:5; cf. $100: 4 ; 123: 9)$ refers to the church as 'the true spiritual Israel' (Richardson 1969: 83; Campbell 1993: 441). (4) The tendency in the first century and beyond not to appropriate the term 'Iopań $\lambda$ for the Judeans of the time,

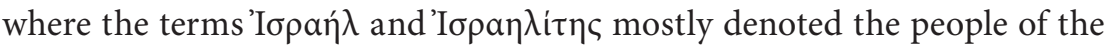
pre-exilic period (esp. Josephus, see above), can be considered as an a priori constraint in envisioning a continuance of Israel in Paul's present. (5) When the qualification 'of God' (6:16) is associated with the identity of Christbelievers elsewhere in Galatians, some other qualifier exists (e.g., Gal 1:13; $2: 20 ; 3: 26)^{18}$ which in turn might suggest that 'the Israel of God' (without any other qualifiers) points to historical Israel. ${ }^{19}(6)$ The qualifier 'of God' would seem to be somewhat out of step with the qualifiers Paul uses in Galatians to point to believers in Christ. ${ }^{20}$ If Paul has Israel of history in mind with the qualifier 'of God' (6:16), such a qualifier would make sense, for he would hardly qualify them as 'Israel according to S/spirit', 'Christ's Israel' or even 'Israel of faith'. In Paul, all of these qualifications normally pertain to the new eschatological age in Christ and the Spirit. There is

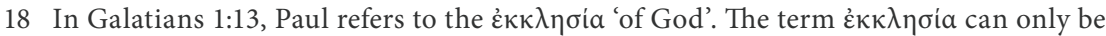
understood here as a designation for believers in Christ, even though he might have the 'universal church' in mind. In the other two locations, 'God' is used in close proximity to another qualifier: 'Son of God' (2:20), and 'of God through faith in Christ Jesus' (3:26).

19 Where 'God' is used in close proximity with 'Israel' elsewhere in Paul, historical Israel is in view. In Rom 9:6-13, Israel is defined around Isaac, Sarah, Rebecca and Jacob, indicating the true, inner historical Israel in distinction from those 'of [the patriarch] Israel' (9:6) that represents national historical Israel. In Rom 11:2, it is about Elijah's pleading against historical Israel, followed by the historical account from $1 \mathrm{Kgs} 19$ of how God has left a remnant (11:3-4). Despite its disputed status, Eph 2:12 in an inverted way seems to be the closest parallel to Gal 6:16 in that the Gentile's former status in the old aeon in the flesh (Eph 2:11) is portrayed as 'without God' while being alienated from 'the citizenship/commonwealth of Israel' (v. 12).

20 E.g., through/of faith, $2: 16 ; 3: 2,7,14,26 ; 5: 5 ; 6: 10$; of/though/in/from the S/spirit, 3:14; $5: 5,16,18,25 ; 6: 8$; in/with Christ, $2: 4,16,17,20 ; 3: 14,17,22,26,27,28 ; 5: 6 ; 6: 15$. 
therefore no compelling reason to differ from Campbell (1993: 442) in his comments on Galatians 6:16, that "[o]nly historical Israel can properly claim the title 'Israel of God". This understanding probably best accounts for Paul's 'out of the blue' (De Boer 2011: 407) reference to 'the Israel of God' over against approaches to this expression that either need to borrow from prevalent interpretations of Romans 9-11 (eschatological) or have to speculate about the exact (ecclesiological) entity that is involved. ${ }^{21}$

\section{Conclusion}

Although Campbell (1993) has argued that 'the Israel of God' in Galatians 6:16 refers to historical Israel, a view that he predominantly bases on critiquing the methodology to infer the meaning of this phrase from one's understanding of Romans 9-11, I have argued that such a reading can be motivated on deeper grounds. I have argued that 'the Israel of God' could in fact refer to those people of God in the previous aeon before the Christ event in contrast to those who walk according to the rule of the new creation (believers in Christ). This reading does not only account for Paul's juxtaposition of the old aeon in the 'flesh' under law with the new aeon in Christ and the Spirit in Galatians, but it also accounts for Paul's view of identity in Christ beyond Galatians, where external, observable markers of identity such as ethnicity, circumcision or law observance are not constitutive of the deeper, controlling criteria for identity of God's people any longer. Christ and the Spirit constitute the new controlling criteria for identity in the new aeon and render all external markers of identity in terms of demarcating God's people obsolete. This does not mean that ethnic identities in Christ are necessarily eradicated as such, but these are not constitutive in demarcating God's people in the new aeon any longer. The notion that ancient Israel's messianic hope has been fulfilled in Christ, although renewed and redrawn, strengthens the notion that Israel as God's people has been fulfilled and completed in Christ in whom a new people came into existence on the basis of new criteria for being God's people. If such an understanding is correct, 'the Israel of God' in Galatians 6:16 could

21 Even De Boer (2011: 407-410) who otherwise resists both a full-blown ecclesiological view or an explicit eschatological view, anticipates in Gal 6:16 Paul's 'same line of thought to Israel' as in Romans 9-11 (ibid.: 408), a methodology that he commendably challenges elsewhere (ibid.: 2; see Wright 2013: 1149). 
only point to historical Israel that lived before the Christ event and in such a way form part of a blessing over all of God's people through all the ages spanning both aeons before and after the Christ event.

\section{Bibliography}

Balz, H; Schneider, G (eds.) 1991. Exegetical Dictionary of the New Testament. Vol. 2. Grand Rapids: Eerdmans.

Barclay, JMG [1988] 1991. Obeying the Truth: Paul's Ethics in Galatians. Minneapolis: Fortress.

Barton, SC (ed.) 2006. The Cambridge Companion to the Gospels.

Cambridge: Cambridge University.

Beker, JC 1982. Paul's Apocalyptic Gospel: The Coming Triumph of God. Philadelphia: Fortress.

Betz, HD 1979. Galatians. Hermeneia. Philadelphia: Fortress.

Bruce, FF 1982. The Epistle of Paul to the Galatians: A Commentary on the Greek Text. NIGTC. Exeter: Paternoster.

Bruce, FF [1985] 2000. Romans. TNTC. Downers Grove, Nottingham: Inter-Varsity.

Buell, DK 2005. Why this New Race: Ethnic Reasoning in Early Christianity. New York: Columbia University Press.

Burton, E deW 1920. A Critical and Exegetical Commentary on the Epistle to the Galatians. ICC. New York: Charles Scribner's Sons.

Campbell, WS 1993. Israel. In Hawthrone \& Martin (eds.) 1993: 441-446.

Campbell, WS 2008. Paul and the Creation of Christian Identity. London: T\&T Clark.

Carson, DA; O'Brien, PT; Seifrid, MA (eds.) 2004. Justification and Variegated Nomism: The Paradoxes in Paul. Vol. II. Tübingen: Mohr Siebeck; Grand Rapids: Baker Academic.

Ciampa, RE; Rosner, BS 2010. The First Letter to the Corinthians. PNTC. Grand Rapids: Eerdmans; Nottingham: Apollos. 
Collins, RF 1999. First Corinthians. SP 7. Collegeville: Liturgical.

Cowan, CW 2010. Context Is Everything: 'The Israel of God' in Galatians 6:16. Southern Baptist Journal of Theology, 14: 78-85.

Cranfield, CEB 1979. A Critical and Exegetical Commentary on The Epistle to the Romans. Vol. II. ICC. Edinburgh: T\&T Clark.

Danker, FW 1989. II Corinthians. ACNT. Minneapolis: Augsburg.

De Boer, MC 2002. Paul, Theologian of God's Apocalypse. Interpretation, 56: 21-33.

De Boer, MC 2011. Galatians: A Commentary. NTL. Louisville:

Westminster John Knox.

Dunn, JDG 1988. Romans. WBC 38a-b. Dallas: Word.

Dunn, JDG 1993. A commentary on the Epistle to the Galatians. BNTC. London: Adam \& Charles Black.

Du Toit, P La G 2013. Paul and Israel: flesh, spirit and identity. Ph.D. Dissertation. Stellenbosch: Stellenbosch University.

Du Toit, P La G 2015. The Salvation of 'All Israel' in Romans 11:2527 as the Salvation of Inner-Elect, Historical Israel in Christ. Neotestamentica, 49(2): 417-452.

Elliott, JH 2007. Jesus the Israelite was neither a 'Jew' nor a 'Christian': On Correcting Misleading Nomenclature. Journal for the Study of the Historical Jesus, 52: 119-154.

Esler, P 2003. Conflict and Identity in Romans: The Social Setting of Paul's Letter. Minneapolis: Fortress.

Evans, CA; Flint, P.W. (eds.) 1997. Eschatology, Messianism, and the Dead Sea Scrolls. Grand Rapids: Eerdmans.

Fee, GD 1994. God's Empowering Presence: The Holy Spirit in the Letters of Paul. Grand Rapids: Baker Academic.

Fee, GD 1996. Paul, the Spirit, and the People of God. Grand Rapids: Baker Academic.

Fitzmyer, JA 1993. Romans. AB. New York: Doubleday. 
Fitzmyer, JA 2007. The One Who Is to Come. Grand Rapids: Eerdmans.

Fitzmyer, JA 2008. First Corinthians: A New Translation with Introduction and Commentary. AYB. New Haven, London: Yale University Press.

Fung, RYK 1988. The Epistle to the Galatians. NICNT. Grand Rapids, Cambridge: Eerdmans.

Gaffin, RB 1998. 'Life-giving Spirit': Probing the Center of Paul's Pneumatology. Journal of the Evangelical Theological Society, 41: 573589.

George, T 1994. Galatians. NAC 30, ePub edition. Broadman \& Holman. Hansen, GW 2009. The Letter to the Philippians. PNTC. Grand Rapids: Eerdmans.

Hawthrone, GF; Martin, R.P. (eds.) 1993. Dictionary of Paul and His Letters. Leicester: Intervarsity.

Hays, RB 2000. The Letter to the Galatians. In Keck (ed.) 2000: 181-348.

Hays, RB 2006. The Canonical Matrix of the Gospels. In Barton (ed.) 2006: 53-75.

Hengel, M 1983. Between Jesus and Paul: Studies in the Earliest History of Christianity. Translated by J. Bowden. Philadelphia: Fortress.

Hodge, CEJ 2007. If Sons, Then Heirs: A Study of Kinship and Ethnicity in the Letters of Paul. New York: Oxford University Press.

Horsley, RA 2001. Hearing the Whole Story: The Politics of Plot in Mark's Gospel. Louisville, London, Leiden: Westminster John Knox.

Horsley, RA; Hanson, J.S. 1985. Bandits, Prophets and Messiahs: Popular Movements at the Time of Jesus. Minneapolis: Winston; Edinburgh: T\&T Clark.

Jewett, R 2007. Romans. Hermeneia. Minneapolis: Fortress.

Johnson, SL 2009. Paul and 'The Israel of God': An Exegetical and Eschatological Case-Study. The Master's Seminary Journal, 20: 41-45.

Käsemann, E 1980. Commentary on Romans. Translated by G. W. Bromiley. London: SCM. 
Keck, LE (ed.) 2000. The New Interpreter's Bible. Vol XI. Nashville: Abingdon.

Keck, LE (ed.) 2002. The New Interpreter's Bible. Vol. X. Nashville: Abingdon.

Knibb, MA 2010. Chapter 17: Apocalypticism and Messianism. In Lim \& Collins (eds.) 2010: 403-432.

Kruse, CG 2012. Paul's Letter to the Romans. PNTC. Grand Rapids: Eerdmans.

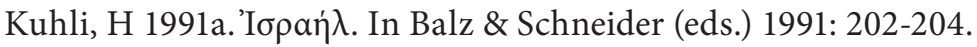

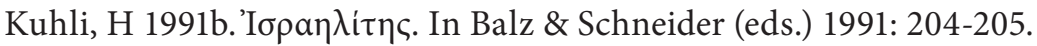

Lategan, BC 1986. Die Brief aan die Galasiërs. Cape Town: N G KerkUitgewers.

Lim, TH; Collins, JH (eds.) 2010. The Oxford Handbook of the Dead Sea Scrolls. Oxford: Oxford University.

Longenecker, RN 1990. Galatians. WBC 41. Dallas: Word.

Martyn, JL 1997. Galatians. AB. New York, London, Toronto, Sydney, Auckland: Doubleday.

Martyn, LL 2000. The Apocalyptic Gospel in Galatians. Interpretation, 54: 246-266.

Mason, S 2007. Jews, Judaeans, Judaizing, Judaism: Problems of Categorization in Ancient History. Journal for the Study of Judaism, 38: 457-512.

Meyer, JC 2009. The End of the Law: Mosaic Covenant in Pauline Theology. ePub edition. Nashville: B \& H Academic.

Miller, DM 2010. The Meaning of Ioudaios and its Relationship to Other Group Labels in Ancient 'Judaism'. Currents in Biblical Research, 9: 98-126.

Miller, DM 2014. Ethnicity, Religion and the Meaning of Ioudaios in Ancient 'Judaism'. Currents in Biblical Research, 12: 216-265. 
Moo, DJ 1996. The Epistle to the Romans. NICNT. Grand Rapids, Cambridge: Eerdmans.

Moo, DJ 2008. The Letters to the Colossians and to Philemon. PNTC. Grand Rapids: Eerdmans; Nottingham: Apollos.

Moo, DJ 2013. Galatians. BECNT. Grand Rapids: Baker Academic.

Neufeld, D 1997. 'And When That One Comes': Aspects of Johannine Messianism. In Evans \& Flint (eds.) 1997: 120-141.

Novenson, MV 2009. The Jewish Messiahs, the Pauline Christ, and the Gentile Question. Journal of Biblical Literature, 128: 357-373.

Perkins, P 2000. The Letter to the Ephesians. In Keck (ed.) 2000: 349-466.

Reventlow, HG (ed.) 1997. Eschatology in the Bible and in Jewish and Christian Tradition. JSOT Supp 243. Sheffield: Sheffield Academic.

Richardson, P 1969. Israel in the Apostolic Church. SNTS 10. Cambridge: Cambridge University.

Sanders, EP [1983] 1989. Paul, the Law, and the Jewish People. Minneapolis: Fortress.

Schreiner, TR 2010. Galatians. ZEC. Grand Rapids: Zondervan.

Sechrest, LL 2009. A Former Jew: Paul and the Dialectics of Race. London: T\&T Clark.

Seifrid, MA 2004. Unrighteous by Faith: Apostolic Proclamation in Romans 1:18-3:20. In Carson et al (eds.) 2004: 105-145.

Thiselton, AC 2000. The First Epistle to the Corinthians. NIGTC. Grand Rapids: Eerdmans; Cambridge: Paternoster.

Tomson, PJ 1986. The Names 'Israel' and 'Jew' in Ancient Judaism and the New Testament. Bijdragen: Tijdschrift voor Filosofie en Theologie, 47: 120-140, 266-289.

Tucker, JB 2010. You belong to Christ: Paul and the formation of social identity in 1 Corinthians 1-4. Eugene: Pickwick.

Tucker, JB 2011. Remain in your calling: Paul and the continuation of social identities in 1 Corinthians. Eugene: Pickwick. 
Weinfeld, M 1997. Expectations of the Divine Kingdom in Biblical and Postbiblical Literature. In Reventlow (ed.) 1997: 218-232.

Wright, NT [1991] 1993. The Climax of the Covenant: Christ and the Law in Pauline Theology. Minneapolis: Fortress.

Wright, NT 1992. The New Testament and the People of God. London: SPCK.

Wright, NT 2002. The Letter to the Romans. In Keck (ed.) 2002: 394-770.

Wright, NT 2003. The Resurrection of the Son of God. London: SPCK.

Wright, NT [2005] 2009. Paul: In Fresh Perspective. Minneapolis: Fortress.

Wright, NT 2013. Paul and the Faithfulness of God. 2 vols. London: SPCK.

Zoccali, C 2010. Whom God Has Called: The Relationship of Church and Israel in Pauline Interpretation, 1920 to the Present. Eugene: Pickwick.

Zoccali, C 2013. Review Article: Paul and social identity in 1 Corinthians. Journal of Beliefs \& Values, 34: 105-114. 